\title{
Inositol 1,4,5-Trisphosphate Receptor Subtype-Specific Regulation of Calcium Oscillations
}

\author{
Songbai Zhang • Nicolas Fritz • Cristian Ibarra • \\ Per Uhlén
}

Accepted: 18 March 2011/Published online: 11 April 2011

(C) The Author(s) 2011. This article is published with open access at Springerlink.com

\begin{abstract}
Oscillatory fluctuations in the cytosolic concentration of free calcium ions $\left(\mathrm{Ca}^{2+}\right)$ are considered a ubiquitous mechanism for controlling multiple cellular processes. Inositol 1,4,5-trisphosphate $\left(\mathrm{IP}_{3}\right)$ receptors $\left(\mathrm{IP}_{3} \mathrm{R}\right)$ are intracellular $\mathrm{Ca}^{2+}$ release channels that mediate $\mathrm{Ca}^{2+}$ release from endoplasmic reticulum (ER) $\mathrm{Ca}^{2+}$ stores. The three $\mathrm{IP}_{3} \mathrm{R}$ subtypes described so far exhibit differential structural, biophysical, and biochemical properties. Subtype specific regulation of $\mathrm{IP}_{3} \mathrm{R}$ by the endogenous modulators $\mathrm{IP}_{3}, \mathrm{Ca}^{2+}$, protein kinases and associated proteins have been thoroughly examined. In this article we will review the contribution of each $\mathrm{IP}_{3} \mathrm{R}$ subtype in shaping cytosolic $\mathrm{Ca}^{2+}$ oscillations.
\end{abstract}

Keywords Inositol 1,4,5-trisphosphate receptor · Inositol 1,4,5-trisphosphate receptor-associated protein $\cdot$ Calcium signaling $\cdot$ Calcium oscillations

\begin{tabular}{|c|c|}
\hline Abbreviations & \\
\hline $\mathrm{Ca}^{2+}$ & Calcium \\
\hline CCK-OP & Cholecystokinin octapeptide \\
\hline $\mathrm{IP}_{3}$ & Inositol 1,4,5-trisphosphate \\
\hline $\mathrm{IP}_{3} \mathrm{R}$ & $\mathrm{IP}_{3}$ receptor \\
\hline $\mathrm{IP}_{3} \mathrm{R} 1,2$ and 3 & $\mathrm{IP}_{3} \mathrm{R}$ subtype 1,2 , and 3 \\
\hline ER & Endoplasmic reticulum \\
\hline PLC & Phospholipase C \\
\hline IICR & $\mathrm{IP}_{3}$-induced $\mathrm{Ca}^{2+}$ release \\
\hline $\mathrm{CaM}$ & Calmodulin \\
\hline
\end{tabular}

Special Issue: In Honor of Dr. Mikoshiba.

S. Zhang · N. Fritz $\cdot$ C. Ibarra $\cdot$ P. Uhlén $(\bowtie)$

Department of Medical Biochemistry and Biophysics,

Karolinska Institutet, 17177 Stockholm, Sweden

e-mail: per.uhlen@ki.se

$\begin{array}{ll}\text { PKA } & \text { cAMP-dependent protein kinase } \\ \text { PKC } & \text { Protein kinase C } \\ \text { CaMKII } & \mathrm{Ca}^{2+} / \mathrm{CaM} \text {-dependent protein kinase II } \\ \text { CTT } & \mathrm{COOH}^{2} \text {-terminal tail } \\ \text { CICR } & \mathrm{Ca}^{2+} \text {-induced } \mathrm{Ca}^{2+} \text { release } \\ \text { AKAP } & \text { PKA-anchoring adaptor protein } \\ \text { LIZ } & \text { leucine/isoleucine zipper } \\ \text { PS } & \text { Presenilin } \\ \text { PS1 and PS2 } & \text { Presenilin-1 and Presenilin-2 } \\ \text { FAD } & \text { Familial Alzheimer's disease } \\ \text { GIT } & \text { G-protein-coupled receptor kinase- } \\ & \text { interacting protein } \\ \text { NCS-1 } & \text { Neuronal Ca }\end{array}$

\section{Introduction}

Intracellular calcium $\left(\mathrm{Ca}^{2+}\right)$ dynamics play pivotal roles in numerous physiological processes, including fertilization, cell proliferation and differentiation, apoptosis, embryonic development, secretion, muscle contraction, immunity, brain function, chemical senses, and light transduction [1, 2]. Two main $\mathrm{Ca}^{2+}$ mobilizing systems co-exist in the cell: $\mathrm{Ca}^{2+}$ influx from the extracellular medium and $\mathrm{Ca}^{2+}$ release from internal stores. The inositol 1,4,5-trisphosphate $\left(\mathrm{IP}_{3}\right)$ receptor $\left(\mathrm{IP}_{3} \mathrm{R}\right)$ is a tetrameric intracellular $\mathrm{IP}_{3^{-}}$ gated $\mathrm{Ca}^{2+}$ release channel that is predominantly located on the membrane of the endoplasmic reticulum (ER). It is present in almost all cell types and plays a crucial role in converting extracellular stimuli into intracellular signals $[1,3]$. Upon extracellular stimulation by various agonists, such as hormones, growth factors, neurotransmitters, neurotrophins, odorants, and light, Phospholipase-C (PLC) is activated and phosphatidylinositol 4,5-bisphosphate is 
hydrolysated, generating $\mathrm{IP}_{3}$. $\mathrm{IP}_{3}$ binds to the $\mathrm{IP}_{3} \mathrm{R}$, leading to the $\mathrm{IP}_{3}$-induced $\mathrm{Ca}^{2+}$ release (IICR) from the ER. Thirty years ago, Mikoshiba et al. found a mutant mouse with deficient Purkinje cells that had very low expression of $\mathrm{P}_{400}$, a glycoprotein that was later uncovered as one of the $\mathrm{IP}_{3} \mathrm{R}$ subtypes $\left(\mathrm{IP}_{3} \mathrm{R} 1\right)[4,5]$. In 1989, Mikoshiba and co-workers were the first group to reveal that $\mathrm{IP}_{3} \mathrm{R}$ is a transmembrane protein and determine the primary sequence of $\mathrm{IP}_{3} \mathrm{R} 1$, at the time the second largest molecule successfully cloned [6]. So far, three $\mathrm{IP}_{3} \mathrm{R}$ subtypes $\left(\mathrm{IP}_{3} \mathrm{R} 1, \mathrm{IP}_{3} \mathrm{R} 2\right.$, $\mathrm{IP}_{3} \mathrm{R} 3$ ) as well as alternative splicing variants of $\mathrm{IP}_{3} \mathrm{R} 1$ and $\mathrm{IP}_{3} \mathrm{R} 2$ have been identified and cloned in mammals [1]. The expression patterns of the three subtypes are distinct but overlapping, and most cells express more than one subtype [7-9]. The three $\mathrm{IP}_{3} \mathrm{R}$ subtypes share $65-85 \%$ homology and can be separated into five functional domains [1, 10-12]. The $\mathrm{NH}_{2}$-terminal region contains a ligand coupling/suppressor domain, which suppresses $\mathrm{IP}_{3^{-}}$ binding activity and determines different $\mathrm{IP}_{3}$-binding affinity for each subtype [13], and an $\mathrm{IP}_{3}$-binding core domain that is the minimum region required for specific $\mathrm{IP}_{3}$ binding [14]. The ligand coupling/suppressor domain and the $\mathrm{IP}_{3}$-binding core are often referred to as the $\mathrm{IP}_{3}$-binding domain. Besides the $\mathrm{IP}_{3}$-binding domain is the internal coupling domain, which confers regulation by various intracellular modulators $\left(\mathrm{Ca}^{2+}\right.$, calmodulin $(\mathrm{CaM})$, ATP) and phosphorylation by several protein kinases (cAMPdependent protein kinase (PKA), protein kinase $\mathrm{C}$ (PKC), cGMP-dependent protein kinase, $\mathrm{Ca}^{2+} / \mathrm{CaM}$-dependent protein kinase II (CamKII), and tyrosine kinase) [3]. The $\mathrm{COOH}$-terminal region has a six membrane-spanning channel domain and a short cytoplasmic $\mathrm{COOH}$-terminal tail (CTT), called the "gatekeeper domain", which is critical for $\mathrm{IP}_{3} \mathrm{R}$ channel opening [10]. The $\mathrm{Ca}^{2+}$ release activity of the $\mathrm{IP}_{3} \mathrm{R}$ channel is therefore regulated by many intracellular modulators $\left(\mathrm{IP}_{3}, \mathrm{Ca}^{2+}, \mathrm{ATP}, \mathrm{CaM}\right)$, protein kinases, and $\mathrm{IP}_{3} \mathrm{R}$-binding proteins $[1,3]$, leading to various spatiotemporal cytosolic $\mathrm{Ca}^{2+}$ patterns and diverse cellular responses $[1,2]$. The relatively low homology in the three $\mathrm{IP}_{3} \mathrm{R}$ subtypes may underlie subtype-specific properties, that will affect $\mathrm{Ca}^{2+}$ signaling and in particular the spatiotemporal features of $\mathrm{Ca}^{2+}$ responses.

A prolonged elevation in the cytosolic $\mathrm{Ca}^{2+}$ concentration is considered toxic to the cell and in some cases may result in cell death. However, the cell can protect itself by temporally limiting the cytosolic $\mathrm{Ca}^{2+}$ elevation, often resulting in one of the most delicate patterns of $\mathrm{Ca}^{2+}$ signals, that being the oscillatory change in the cytosolic $\mathrm{Ca}^{2+}$ concentration, or $\mathrm{Ca}^{2+}$ oscillations [15-17]. Extensive studies over the past 30 years have revealed that cytosolic $\mathrm{Ca}^{2+}$ oscillations are ubiquitous and diverse cellular signals that control multiple processes in the cell. With cytosolic $\mathrm{Ca}^{2+}$ oscillations, cells not only avoid deleterious effects of sustained cytosolic $\mathrm{Ca}^{2+}$ concentrations, but also send out information encoded in the frequency and/or the amplitude of the oscillations to modulate cellular activity [15]. This review focuses on the separate role of the $\mathrm{IP}_{3} \mathrm{R}$ subtypes in generating $\mathrm{Ca}^{2+}$ oscillations and on the molecular mechanisms responsible for the specific role of each subtype in regulating this ubiquitous signal.

\section{A General Mechanism Generating $\mathrm{Ca}^{2+}$ Oscillations Based on Regulation of $I_{3} R$}

Many studies have indicated that $\mathrm{IP}_{3} \mathrm{R}$ is involved in generating cytosolic $\mathrm{Ca}^{2+}$ oscillations [15-17]. For instance, the FGF-induced $\mathrm{Ca}^{2+}$ oscillations in mice fibroblasts are inhibited by an $\mathrm{IP}_{3} \mathrm{R}$ antagonist [18]. $\mathrm{Ca}^{2+}$ oscillations are thought to arise due to periodic release of $\mathrm{Ca}^{2+}$ from intracellular $\mathrm{Ca}^{2+}$ stores via $\mathrm{IP}_{3} \mathrm{R}$ [19]. Early studies using reconstituted $\mathrm{IP}_{3} \mathrm{R}$ in lipid bilayers have indicated that $\mathrm{Ca}^{2+}$ can both activate and inhibit $\mathrm{IP}_{3} \mathrm{R}[20$, 21]. The $\mathrm{IP}_{3} \mathrm{R}$ is activated at low cytosolic $\mathrm{Ca}^{2+}$ concentrations, elevating the cytosolic $\mathrm{Ca}^{2+}$ concentration through a process often referred to as $\mathrm{Ca}^{2+}$-induced $\mathrm{Ca}^{2+}$ release (CICR). High cytosolic $\mathrm{Ca}^{2+}$ concentration can instead inhibit $\mathrm{IP}_{3} \mathrm{R}$, leading to a decrease in intracellular $\mathrm{Ca}^{2+}$ release. In vivo, the binding of $\mathrm{IP}_{3}$ together with fluctuating cytosolic $\mathrm{Ca}^{2+}$ concentrations can trigger successive cycles of $\mathrm{IP}_{3} \mathrm{R}$ activation and inhibition, which result in cytosolic $\mathrm{Ca}^{2+}$ oscillations. Accordingly, $\mathrm{Ca}^{2+}$ oscillations can be produced by application of $\mathrm{IP}_{3}$ to permeabilized hepatocytes [22] and blowfly salivary gland cells [23] and by injecting $\mathrm{IP}_{3}$ analogs into fertilized ascidians eggs [24]. Moreover, DT40 cells expressing a mutant $\mathrm{IP}_{3} \mathrm{R}$ with reduced sensitivity to $\mathrm{Ca}^{2+}$ do not exhibit $\mathrm{Ca}^{2+}$ oscillations upon application of cross-linked B-cell receptors [25]. Finally, thimerosal, which sensitizes $\mathrm{IP}_{3} \mathrm{R}$ for lower $\mathrm{IP}_{3}$ levels, potentiates $\mathrm{IP}_{3}$-induced $\mathrm{Ca}^{2+}$ oscillations in sea urchin eggs [26]. These data, together with mathematical models [27, 28], have confirmed that the cross-talk between $\mathrm{Ca}^{2+}$ and $\mathrm{IP}_{3}$ in regulating the $\mathrm{IP}_{3} \mathrm{R}$ is critical for generating $\mathrm{Ca}^{2+}$ oscillations. However, in Madin-Darby canine kidney epithelial cells [29] and Chinese hamster ovary cells [30-32], each peak of the oscillatory $\mathrm{Ca}^{2+}$ signal is preceded by elevated $\mathrm{IP}_{3}$, as measured by means of a pleckstrin homology domain of PLC- $\delta_{1}$ tagged with a fluorescent protein indicator. Therefore, it has been proposed that dynamic $\mathrm{IP}_{3}$ production may produce cytosolic $\mathrm{Ca}^{2+}$ oscillations. Nevertheless, other studies using different cells and methods reported opposite conclusions [33-35]. For example, expression of an $\mathrm{IP}_{3}$ binding domain of $\mathrm{IP}_{3} \mathrm{R} 1$ together with two different fluorescent proteins in $\mathrm{HeLa}$ cells does not reveal fluctuations in the intracellular $\mathrm{IP}_{3}$ concentration during $\mathrm{Ca}^{2+}$ oscillations [33]. 


\section{Subtype Specificity of $\mathrm{Ca}^{2+}$ Oscillations}

Numerous studies using cells endogenously or exogenously expressing single or combined $\mathrm{IP}_{3} \mathrm{R}$ subtypes indicate that the subtle distinctions in the properties of each subtype contribute differently to the regulation of cytosolic $\mathrm{Ca}^{2+}$ oscillations [3].

Miyakawa et al. [36] first described $\mathrm{IP}_{3} \mathrm{R}$ subtype-specific $\mathrm{Ca}^{2+}$ oscillations using genetically engineered $\mathrm{B}$ cells that express either single or combined $\mathrm{IP}_{3} \mathrm{R}$ subtypes. They found that $\mathrm{Ca}^{2+}$-signaling patterns depend on the expression levels of $\mathrm{IP}_{3} \mathrm{R}$ subtypes, probably because of their specific response to endogenous modulators, such as $\mathrm{IP}_{3}$, $\mathrm{Ca}^{2+}$ and ATP. IP 3 R2 is the most sensitive to $\mathrm{IP}_{3}$ and is required for robust, long lasting, and regular $\mathrm{Ca}^{2+}$ oscillations that occur upon activation of B-cell receptors. $\mathrm{IP}_{3} \mathrm{R} 1$ mediates less regular $\mathrm{Ca}^{2+}$ oscillations. $\mathrm{IP}_{3} \mathrm{R} 3$ is the least sensitive to $\mathrm{IP}_{3}$ as well as $\mathrm{Ca}^{2+}$ and generates only monophasic $\mathrm{Ca}^{2+}$ transients. Morel et al. [37] examined the roles of $\mathrm{IP}_{3} \mathrm{R} 1$ and $\mathrm{IP}_{3} \mathrm{R} 2$ in $\mathrm{Ca}^{2+}$ oscillations using vascular myocytes and found that acetylcholine induces $\mathrm{Ca}^{2+}$ oscillations in cells expressing both subtypes, and fails to do so in cells expressing only $\mathrm{IP}_{3} \mathrm{R} 1$. The oscillations are inhibited by intracellular infusion of heparin, anti-IP ${ }_{3} \mathrm{R} 2$ antibody or antisense oligonucleotides targeting $\mathrm{IP}_{3} \mathrm{R} 2$, suggesting that the $\mathrm{IP}_{3} \mathrm{R} 2$ subtype is required for acetylcholine-induced $\mathrm{Ca}^{2+}$ oscillations in vascular myocytes. Using HeLa cells, which express comparable amounts of $\mathrm{IP}_{3} \mathrm{R} 1$ and $\mathrm{IP}_{3} \mathrm{R} 3$, Mikoshiba and co-workers showed that knockdown of $\mathrm{IP}_{3} \mathrm{R} 1$ terminates $\mathrm{Ca}^{2+}$ oscillations, whereas knockdown of $\mathrm{IP}_{3} \mathrm{R} 3$ leads to more robust and long lasting $\mathrm{Ca}^{2+}$ oscillations [38]. These $\mathrm{IP}_{3} \mathrm{R} 3$ knockdown effects were similar in COS-7 cells that predominantly express $\mathrm{IP}_{3} \mathrm{R} 3$, suggesting that $\mathrm{IP}_{3} \mathrm{R} 3$ functions as an anti $\mathrm{Ca}^{2+}$ oscillatory unit. Almirza et al. reported similar results using normal kidney fibroblasts, which expresses $\mathrm{IP}_{3} \mathrm{R} 1$ and $\mathrm{IP}_{3} \mathrm{R} 3$ [39]. When $\mathrm{IP}_{3} \mathrm{R} 1$ or $\mathrm{IP}_{3} \mathrm{R} 3$ are knocked-down, the frequency of prostaglandin $\mathrm{F}_{2 \alpha}$-induced $\mathrm{Ca}^{2+}$ oscillations is significantly decreased or increased, respectively. In NIH$3 \mathrm{~T} 3$ cells, which predominantly express $\mathrm{IP}_{3} \mathrm{R} 2$ and $\mathrm{IP}_{3} \mathrm{R} 3$, ATP activates $\mathrm{Ca}^{2+}$ oscillations [40]. $\mathrm{Ca}^{2+}$ oscillations were induced by application of carbachol in AR4-2J cells, which predominantly expresses $\mathrm{IP}_{3} \mathrm{R} 2$, and in HEK293A cells in which both $\mathrm{IP}_{3} \mathrm{R} 1$ and $\mathrm{IP}_{3} \mathrm{R} 3$ were knocked-down [41]. The contribution of $\mathrm{IP}_{3} \mathrm{R} 2$ to $\mathrm{Ca}^{2+}$ oscillations is further confirmed by the fact that $\mathrm{IP}_{3}$-dependent $\mathrm{Ca}^{2+}$ oscillations were abolished in osteoclasts of $\mathrm{IP}_{3} \mathrm{R} 2$ knockout mice [42]. In rat insulinoma RINm5F cells, which almost exclusively express $\mathrm{IP}_{3} \mathrm{R} 3$, application of carbachol or EGF, two agonists that activate PLC through different receptors, or application of $\mathrm{IP}_{3}$ to permeabilized cells, elicit transient $\mathrm{Ca}^{2+}$ release and does not induce $\mathrm{Ca}^{2+}$ oscillations [43]. Several reports, including mathematical modeling studies, have indicated that the specific intracellular localization of the $\mathrm{IP}_{3} \mathrm{R}$ is crucial for the generation of $\mathrm{Ca}^{2+}$ oscillations [44-46]. For instance, Kim et al. [45] found that HL- 1 cells derived from mouse cardiac myocytes express both $I_{3} R 1$ and $I_{3} R 2$. IP $2 R 1$ is expressed diffusely in the perinucleus and $\mathrm{IP}_{3} \mathrm{R} 2$ is expressed in the cytosol with a punctuated distribution. Both application of ATP to intact cells and direct introduction of $\mathrm{IP}_{3}$ into permeabilized cells evoke $\mathrm{IP}_{3}$-dependent transient intracellular $\mathrm{Ca}^{2+}$ release accompanied by $\mathrm{Ca}^{2+}$ oscillations. The magnitude of $\mathrm{Ca}^{2+}$ oscillations is significantly larger in the cytosol than in the nucleus, while the monophasic $\mathrm{Ca}^{2+}$ transient is more pronounced in the nucleus. These results suggest that subtype specificity as well as specific localization of the $\mathrm{IP}_{3} \mathrm{R}$ contribute to distinct local $\mathrm{Ca}^{2+}$ signaling. Altogether, these data suggest that $\mathrm{IP}_{3} \mathrm{R} 1$ and $I_{3} R 2$, in particular $I_{3} R 2$, crucially contribute in generating $\mathrm{Ca}^{2+}$ oscillations, whereas $\mathrm{IP}_{3} \mathrm{R} 3$ is an anti-oscillatory unit. Nevertheless, in A7r5 cells derived from rat embryonic thoracic aorta muscle cells, which express $\mathrm{IP}_{3} \mathrm{R} 1$ and $\mathrm{IP}_{3} \mathrm{R} 3$, knockdown of $\mathrm{IP}_{3} \mathrm{R} 1$ only reduces the frequency of arginine vasopressin-induced $\mathrm{Ca}^{2+}$ oscillations without affecting the number of cells exhibiting $\mathrm{Ca}^{2+}$ oscillations [47]. Moreover, both acetylcholine and cholecystokinin octapeptide activate $\mathrm{IP}_{3} \mathrm{R} 2$ - and $\mathrm{IP}_{3} \mathrm{R} 3$-dependent $\mathrm{Ca}^{2+}$ oscillations in pancreatic acinar cells. However, unlike $\mathrm{IP}_{3} \mathrm{R} 2$-dependent oscillations, the amplitude of $\mathrm{IP}_{3} \mathrm{R} 3$-dependent oscillations decreases throughout the stimulation [48]. The $\mathrm{IP}_{3} \mathrm{R}$ subtype-specific $\mathrm{Ca}^{2+}$ oscillations are summarized in Table 1.

The $\mathrm{IP}_{3} \mathrm{R}$ exists as a homo- or hetero-tetrameric complex to form a functional $\mathrm{Ca}^{2+}$ release channel [49-51] . The influence of homo- or hetero-tetrameric channels on intracellular $\mathrm{Ca}^{2+}$ oscillations has been investigated. Studies on genetically engineered DT40 cells that express a single $\mathrm{IP}_{3} \mathrm{R}$ subtype and therefore a homo-tetrameric receptor demonstrate $\mathrm{Ca}^{2+}$ oscillations [36]. Cells with all subtypes, which should at least partially express heterotetrameric $\mathrm{IP}_{3} \mathrm{Rs}$, also exhibit $\mathrm{Ca}^{2+}$ oscillations [37-43, 45, 47]. Taken together these data suggest that both homo- and hetero-tetrameric $\mathrm{IP}_{3} \mathrm{Rs}$ can generate intracellular $\mathrm{Ca}^{2+}$ oscillations.

In conclusion, it appears that $\mathrm{IP}_{3} \mathrm{R}$ subtype-specific expression crucially shapes cytosolic $\mathrm{Ca}^{2+}$ signaling patterns. $\mathrm{IP}_{3} \mathrm{R} 2$ is the main pro-oscillatory subtype, whereas $\mathrm{IP}_{3} \mathrm{R} 1$ can induce a transient $\mathrm{Ca}^{2+}$ signal or an oscillatory $\mathrm{Ca}^{2+}$ signal. $\mathrm{IP}_{3} \mathrm{R} 3$ mainly shows an anti-oscillatory behavior, but could underlie short-term oscillations depending on the cell type and stimulus. Further characterization of homo- and hetero-tetrameric $\mathrm{IP}_{3} \mathrm{R}$-dependent $\mathrm{Ca}^{2+}$ oscillations are needed for fully understanding the intricacies of each $\mathrm{IP}_{3} \mathrm{R}$ subunit in shaping $\mathrm{Ca}^{2+}$ oscillations. 
Table 1 The occurrence of $\mathrm{Ca}^{2+}$ oscillations and the expression of the different $\mathrm{IP}_{3} \mathrm{R}$ subtypes

\begin{tabular}{|c|c|c|c|c|c|c|}
\hline Cell type & $\mathrm{IP}_{3} \mathrm{R} 1$ & $\mathrm{IP}_{3} \mathrm{R} 2$ & $\mathrm{IP}_{3} \mathrm{R} 3$ & Activator & $\mathrm{Ca}^{2+}$ oscillations & $\overline{\text { Reference }}$ \\
\hline DT40 & + & - & - & B cell receptor & $\uparrow$ & {$[36]$} \\
\hline DT40 & - & + & - & B cell receptor & $\uparrow$ & {$[36]$} \\
\hline DT40 & - & - & + & B cell receptor & $\downarrow$ & {$[36]$} \\
\hline Vascular myocytes & + & + & - & Acetylcholine & $\uparrow$ & {$[37]$} \\
\hline Vascular myocytes & + & - & - & Acetylcholine & $\downarrow$ & {$[37]$} \\
\hline $\mathrm{HeLa}$ & ++ & + & $++(\mathrm{kd})$ & ATP & $\uparrow$ & {$[38]$} \\
\hline $\mathrm{HeLa}$ & $++(\mathrm{kd})$ & + & ++ & ATP & $\downarrow$ & {$[38]$} \\
\hline COS-7 & + & + & $++(\mathrm{kd})$ & ATP & $\uparrow$ & {$[38]$} \\
\hline NRK & + & - & $+(\mathrm{kd})$ & Prostaglandin $\mathrm{F}_{2 \alpha}$ & $\uparrow$ & [39] \\
\hline NRK & $+(\mathrm{kd})$ & - & + & Prostaglandin $\mathrm{F}_{2 \alpha}$ & $\downarrow$ & [39] \\
\hline NIH-3T3 & + & ++ & ++ & ATP & $\uparrow$ & {$[40]$} \\
\hline AR4-2 J & + & ++ & + & IGF-1 & $\uparrow$ & {$[41]$} \\
\hline HEK293A & $+(\mathrm{kd})$ & + & $+(\mathrm{kd})$ & Carbachol & $\uparrow$ & {$[41]$} \\
\hline Osteoclasts & + & + & + & RANKL & $\uparrow$ & {$[42]$} \\
\hline Osteoclasts & + & - & + & RANKL & $\downarrow$ & {$[42]$} \\
\hline Osteoclasts & + & - & - & RANKL & $\downarrow$ & {$[42]$} \\
\hline RINm5F & \pm & \pm & ++ & Carbachol, EGF, $\mathrm{IP}_{3}$ & $\downarrow$ & [43] \\
\hline HL-1 & + & + & - & ATP & $\uparrow$ & {$[45]$} \\
\hline $\mathrm{A} 7 \mathrm{r} 5$ & $+(\mathrm{kd})$ & - & + & Arginine vasopressin & $\downarrow$ & {$[47]$} \\
\hline Pancreatic acinar cells & + & + & + & Acetylcholine, CCK-OP & $\uparrow$ & [48] \\
\hline Pancreatic acinar cells & + & - & + & Acetylcholine, CCK-OP & $\uparrow$ & {$[48]$} \\
\hline
\end{tabular}

+ high expression, - low expression, and kd, knock down or low expression

\section{Subtype Specificity of $\mathrm{IP}_{\mathbf{3}}$-Binding Affinity to $\mathrm{IP}_{\mathbf{3}} \mathbf{R}$}

As summarized earlier, cytosolic $\mathrm{Ca}^{2+}$ oscillations are $\mathrm{IP}_{3} \mathrm{R}$ subtype-dependent. $\mathrm{IP}_{3}$ and $\mathrm{Ca}^{2+}$ are the two key modulators of $\mathrm{IP}_{3} \mathrm{R}$ and the distinct subtype properties determine the diverse regulatory effects. Each subtype has different $\mathrm{IP}_{3}$ binding affinity. Sudhof et al. were first to report, using an equilibrium $\mathrm{IP}_{3}$ binding assay, that the order of IP $\mathrm{IP}_{3}$-binding affinity was $\mathrm{IP}_{3} \mathrm{R} 2>\mathrm{IP}_{3} \mathrm{R} 1>\mathrm{IP}_{3} \mathrm{R} 3$ $[9,52]$. Applying the same method, Wojcikiewicz et al. [53] and Nerou et al. [54] later claimed a different order, $I_{3} R 1>I_{3} R 2>I P_{3} R 3$. Mikoshiba and co-workers performed a detailed molecular analysis of the $\mathrm{IP}_{3}$ binding affinity of all three subtypes $[11,13]$. They found that the $\mathrm{IP}_{3}$-binding affinities of purified $\mathrm{IP}_{3}$-binding domains are close to the intrinsic $\mathrm{IP}_{3}$-binding affinity of all three $\mathrm{IP}_{3} \mathrm{R}$ subtypes, and describe the following order $\mathrm{IP}_{3} \mathrm{R} 2>$ $\mathrm{IP}_{3} \mathrm{R} 1>\mathrm{IP}_{3} \mathrm{R} 3$. They also showed that $\mathrm{IP}_{3}$-binding core fragments, which do not contain the ligand coupling/suppressor domain, display an almost identical $\mathrm{IP}_{3}$-binding affinity for all three subtypes. By a serious and compelling molecular analysis, they concluded that the functional diversity in ligand sensitivity among $\mathrm{IP}_{3} \mathrm{R}$ subtypes arises from structural differences in the ligand coupling/suppressor domain, which attenuate the $\mathrm{IP}_{3}$-binding affinity of the $\mathrm{IP}_{3}$-binding core domain through an intramolecular mechanism. Tu et al. recorded single-channel activities of the recombinant $I_{3} R 1, I P_{3} R 2$, and $I_{3} R 3$ reconstituted into planar lipid bilayers [55]. This report had a similar conclusion with $\mathrm{IP}_{3} \mathrm{R} 2$ showing the highest apparent $\mathrm{IP}_{3}$-affinity, followed by $\mathrm{IP}_{3} \mathrm{R} 1$, and then by $\mathrm{IP}_{3} \mathrm{R} 3$.

Differences amongst $\mathrm{IP}_{3} \mathrm{R}$ subtypes in terms of $\mathrm{IP}_{3}$-binding affinities do not reflect intrinsic differences in the properties of the channels to regulate $\mathrm{Ca}^{2+}$ oscillations. Instead differences in the state of phosphorylation and/or association with interacting proteins exist. Nevertheless, $\mathrm{IP}_{3} \mathrm{R} 1$ and $\mathrm{IP}_{3} \mathrm{R} 2$ are most sensitive to $\mathrm{IP}_{3}$, a property that could contribute in their function as $\mathrm{Ca}^{2+}$ oscillatory unit. The exact contribution of subtype specific $\mathrm{IP}_{3}$-binding affinities on $\mathrm{Ca}^{2+}$ oscillations remains to be further investigated.

\section{Subtype Specificity of $\mathrm{Ca}^{2+}$ Inhibition and Induction}

As mentioned earlier, repeated activation and inhibition of IICR by fluctuating cytosolic $\mathrm{Ca}^{2+}$ levels have been proposed as central molecular mechanisms for $\mathrm{IP}_{3} \mathrm{R}$-dependent $\mathrm{Ca}^{2+}$ oscillations [56]. Several stimulatory and inhibitory $\mathrm{Ca}^{2+}$ binding sites on the $\mathrm{IP}_{3} \mathrm{R}$ have been identified and characterized. For instance, two sites are localized in the 
$\mathrm{IP}_{3}$ binding core and another site is located close to the transmembrane domain [57], exemplifying the complex synergy between $\mathrm{IP}_{3}$ and $\mathrm{Ca}^{2+}$ in the regulation of the IICR [12]. $\mathrm{Ca}^{2+}$ regulation of $\mathrm{IP}_{3} \mathrm{R}$ activity may result in changed $\mathrm{IP}_{3}$ binding affinity, alteration of channel open probability, or indirect influence on $\mathrm{IP}_{3} \mathrm{R}$ associated proteins, such as the CaM. Interestingly, this can occur specifically on one $\mathrm{IP}_{3} \mathrm{R}$ subtype, making $\mathrm{Ca}^{2+}$ regulation of IICR one of the major mechanisms to produce versatile signals, as confirmed by mathematical modeling studies [58].

The complex regulation of the $\mathrm{IP}_{3} \mathrm{R}$ subtypes' activity by $\mathrm{Ca}^{2+}$ has been recently reviewed in detail [3] and we will therefore mainly focus on how $\mathrm{Ca}^{2+}$ itself modulates $\mathrm{Ca}^{2+}$ oscillations. Everyone in the field agrees that all three subtypes are activated by $\mathrm{Ca}^{2+}$. Inhibition of the $\mathrm{IP}_{3} \mathrm{R}$ by $\mathrm{Ca}^{2+}$, however, is more controversial. In single channel studies, each subtype is inhibited by high $\mathrm{Ca}^{2+}$ concentrations, even though the threshold and speed of inhibition differs [3]. Moreover, $\mathrm{Ca}^{2+}$ inhibition of IICR sometimes depends on the addition of an extra factor, for example ATP for $\mathrm{IP}_{3} \mathrm{R} 3$ [55]. Therefore, all three subtypes can potentially support $\mathrm{Ca}^{2+}$ oscillations based on the model described previously, where concerted actions of $\mathrm{IP}_{3}$ and $\mathrm{Ca}^{2+}$ stimulates $\mathrm{IP}_{3} \mathrm{R}$. Accordingly, $\mathrm{IP}_{3} \mathrm{R} 1-, \mathrm{IP}_{3} \mathrm{R} 2-$, and $\mathrm{IP}_{3} \mathrm{R} 3$-dependent $\mathrm{Ca}^{2+}$ oscillations have been observed, although $\mathrm{IP}_{3} \mathrm{R} 3$-dependent $\mathrm{Ca}^{2+}$ oscillations are less likely to occur and are also less frequently observed (see previous sections).

In most cases, cells express more than one $\mathrm{IP}_{3} \mathrm{R}$ subtype. Interestingly, when several $\mathrm{IP}_{3} \mathrm{R}$ subtypes are expressed, one of them becomes dominant regarding $\mathrm{Ca}^{2+}$ regulation of IICR [36]. This result also calls for caution when drawing conclusions on the subtype specificity of $\mathrm{Ca}^{2+}$ signaling, since expression of even a small amount of one subtype could critically affect the $\mathrm{Ca}^{2+}$ signaling pattern [59].

Taken together, $\mathrm{Ca}^{2+}$ activation and inhibition properties of $\mathrm{IP}_{3} \mathrm{R} 1$ and $\mathrm{IP}_{3} \mathrm{R} 2$ make them likely to support $\mathrm{Ca}^{2+}$ oscillations in physiological conditions [60], whereas specific cellular circumstances are required for activation of $\mathrm{IP}_{3} \mathrm{R} 3$-dependent $\mathrm{Ca}^{2+}$ oscillations.

\section{Subtype Specificity of Phosphorylation of $\mathrm{IP}_{\mathbf{3}} \mathrm{R}$}

Phosphorylation of the $\mathrm{IP}_{3} \mathrm{R}$ is involved in many $\mathrm{Ca}^{2+}$ signaling pathways [61] and the different subtypes are interacting with protein kinases and phosphatases differently [62]. Many of the phosphorylation sites are subtypespecific, increasing the diversity in regulatory fine tuning of $\mathrm{Ca}^{2+}$ oscillations. The functional consequences of these regulatory modifications are only partially understood, and in some cases remain controversial. Therefore we will here focus on those protein kinases known to modulate $\mathrm{Ca}^{2+}$ oscillations through phosphorylation of $\mathrm{IP}_{3} \mathrm{R}$.
PKA-dependent phosphorylation of $\mathrm{IP}_{3} \mathrm{R}$ has been demonstrated extensively. Phosphomimetic mutations of $\mathrm{IP}_{3} \mathrm{R} 1$ expressed in DT40 cells showed that PKA-mediated phosphorylation decreases the threshold for $\mathrm{Ca}^{2+}$ oscillations, without affecting the amplitude or frequency [63]. PKA phosphorylates two distinct sites in $\mathrm{IP}_{3} \mathrm{R} 1$ internal coupling domain (S1588 and S1755) [64]. Although these sites are not conserved in $\mathrm{IP}_{3} \mathrm{R} 2$ and $\mathrm{IP}_{3} \mathrm{R} 3$, PKA-dependent phosphorylation of these subtypes has been demonstrated [65]. In parotid acinar cells [66] and the pancreatic AR4-2J cell line [67], PKA directly phosphorylates $\mathrm{IP}_{3} \mathrm{R} 2$, dramatically potentiating $\mathrm{Ca}^{2+}$ release. Interestingly, raising cAMP during sub-threshold agonist stimulation resulted in an oscillatory $\mathrm{Ca}^{2+}$ signal, while raising cAMP during an $\mathrm{Ca}^{2+}$ oscillation converted the response into a peak and plateau-like signal [66], probably because of a shift in the concentration dependency in IICR. CaMKII has been proposed to be involved in the control of the $\mathrm{Ca}^{2+}$ dependent regulation of IICR and in the occurrence of $\mathrm{Ca}^{2+}$ oscillations [68]. The most extensive information regarding CaMKII regulation of $\mathrm{IP}_{3} \mathrm{R}$ is derived from studies performed on $\mathrm{IP}_{3} \mathrm{R} 2[69,70]$, which is the predominant subtype in cardiac ventricular myocytes. CaMKII-dependent phosphorylation significantly decreased the open probability of $\mathrm{IP}_{3} \mathrm{R} 2$ in lipid bilayers, which suggests a $\mathrm{Ca}^{2+}$-dependent negative feedback mechanism on $\mathrm{IP}_{3} \mathrm{R} 2$ activity in the cardiomyocyte nuclear envelope [71]. This may also result in a $\mathrm{Ca}^{2+}$-dependent inhibitory loop of $\mathrm{Ca}^{2+}$ oscillations [72]. Functional effects of PKC-mediated phosphorylation of the $\mathrm{IP}_{3} \mathrm{R}$ were first studied in isolated rat liver nuclei [73]. PKC-mediated phosphorylation of $\mathrm{IP}_{3} \mathrm{R} 1$ in vitro is in addition regulated by $\mathrm{Ca}^{2+}$ and $\mathrm{CaM}$ [74]. As both $\mathrm{Ca}^{2+}$ and CaM inhibit the PKC-mediated phosphorylation of $\mathrm{IP}_{3} \mathrm{R} 1$, it is possible that this process may contribute to the negative slope of the $\mathrm{Ca}^{2+}$-dependent bell-shaped regulation of $\mathrm{IP}_{3} \mathrm{R}$ by $\mathrm{Ca}^{2+}$, consequently affecting $\mathrm{Ca}^{2+}$ oscillations. Recent demonstrations suggest a role for PKC-mediated phosphorylation of $\mathrm{IP}_{3} \mathrm{R} 2$ [75] and $\mathrm{IP}_{3} \mathrm{R} 3$ [43]. These reports show that when $\mathrm{IP}_{3} \mathrm{R} 2$ or $\mathrm{IP}_{3} \mathrm{R} 3$ are phosphorylated by $\mathrm{PKC}$, $\mathrm{IP}_{3}$-dependent $\mathrm{Ca}^{2+}$ oscillations are decreased in cells expressing only those subtypes. Thus, PKC may act as a subtype specific regulator of $\mathrm{IP}_{3} \mathrm{R}$-mediated cytosolic $\mathrm{Ca}^{2+}$ oscillations. These differences are not unexpected since $\mathrm{IP}_{3} \mathrm{R}$ subtypes possess different potential phosphorylation sites [43, 76]. How phosphorylation of $\mathrm{IP}_{3} \mathrm{R}$ subtypes by distinct protein kinases affect $\mathrm{Ca}^{2+}$ oscillations are summarized in Table 2.

The subtype specific regulation of $\mathrm{IP}_{3} \mathrm{R}$ by phosphorylation and its relation to $\mathrm{Ca}^{2+}$ oscillations are not fully understood. These processes are likely to be dependent on specific $\mathrm{IP}_{3} \mathrm{R}$ subtypes expression levels and protein kinases activation, and need to be further investigated. 
Table 2 The $\mathrm{IP}_{3} \mathrm{R}$ subtype specificity of protein kinases and $\mathrm{IP}_{3} \mathrm{R}$-associated proteins and their modulating effects on $\mathrm{Ca}^{2+}$ oscillations

\begin{tabular}{|c|c|c|c|c|c|c|}
\hline \multirow{2}{*}{$\begin{array}{l}\text { Effect } \\
\text { Effectors }\end{array}$} & \multicolumn{3}{|l|}{ Stimulatory } & \multicolumn{3}{|l|}{ Inhibitory } \\
\hline & $\mathrm{IP}_{3} \mathrm{R} 1$ & $\mathrm{IP}_{3} \mathrm{R} 2$ & $\mathrm{IP}_{3} \mathrm{R} 3$ & $\mathrm{IP}_{3} \mathrm{R} 1$ & $\mathrm{IP}_{3} \mathrm{R} 2$ & $\mathrm{IP}_{3} \mathrm{R} 3$ \\
\hline $\mathrm{PKC}$ & {$[73,74]$} & - & - & - & {$[75]$} & {$[43]$} \\
\hline PKA & {$[63]$} & {$[67]$} & - & - & {$[67]$} & - \\
\hline CaMKII & - & - & - & {$[68][72]$} & - & - \\
\hline $\mathrm{CaBP} 1$ & - & - & - & {$[82]$} & - & [82] \\
\hline Na,K-ATPase & {$[83,84]$} & {$[83,84]$} & {$[83,84]$} & - & - & - \\
\hline IRBIT & - & - & - & {$[85]$} & - & - \\
\hline AKAP9 & [87] & - & - & - & - & - \\
\hline PS1/PS2 & {$[88,89]$} & {$[88,89]$} & {$[88,89]$} & - & - & - \\
\hline ERp44 & - & - & - & {$[90]$} & - & - \\
\hline GRP78 & [91] & - & - & - & - & - \\
\hline Bcl-2 & {$[78,92,94,96]$} & {$[78,92,94,96]$} & {$[78,92,94,96]$} & [97] & [97] & [97] \\
\hline Bcl-X ${ }_{L}$ & {$[93,95]$} & {$[93,95]$} & {$[93,95]$} & - & - & - \\
\hline Mcl-1 & {$[78]$} & {$[78]$} & {$[78]$} & - & - & - \\
\hline Cytochrome C & {$[98,99]$} & - & - & - & - & - \\
\hline GIT1/GIT2 & - & - & - & [81] & [81] & [81] \\
\hline NCS-1 & {$[80,100]$} & {$[80,100]$} & {$[80,100]$} & - & - & - \\
\hline
\end{tabular}

\section{Regulation of $\mathrm{IP}_{3} \mathrm{R}$ Activity by Accessory Proteins}

About forty proteins have been reported to interact with $\mathrm{IP}_{3} \mathrm{R}$, most of which modulate $\mathrm{IP}_{3} \mathrm{R}$ channel activity $[1,3,77-81]$. There is a lack of data regarding $\mathrm{IP}_{3} \mathrm{R} 2$ and $\mathrm{IP}_{3} \mathrm{R} 3$ specific binding proteins since most of these proteins are identified by co-immunoprecipitation studies with one or two $\mathrm{IP}_{3} \mathrm{R}$ subtypes or using $\mathrm{IP}_{3} \mathrm{R} 1$ probes. Few reports show that some of these associated proteins modulate $\mathrm{Ca}^{2+}$ oscillations differently. Therefore, we summarize here the proteins that bind to $\mathrm{IP}_{3} \mathrm{R}$ and modulate $\mathrm{Ca}^{2+}$ oscillations, whether they bind to a specific $\mathrm{IP}_{3} \mathrm{R}$ subtype or not (Table 2; Fig. 1).
Fig. 1 Cartoon illustrating the three $\mathrm{IP}_{3} \mathrm{R}$ subtypes $\left(\mathrm{IP}_{3} \mathrm{R} 1\right.$, $\mathrm{IP}_{3} \mathrm{R} 2$, and $\mathrm{IP}_{3} \mathrm{R} 3$ ) and related protein kinases and interacting proteins involved in the regulation of cytosolic $\mathrm{Ca}^{2+}$ oscillations

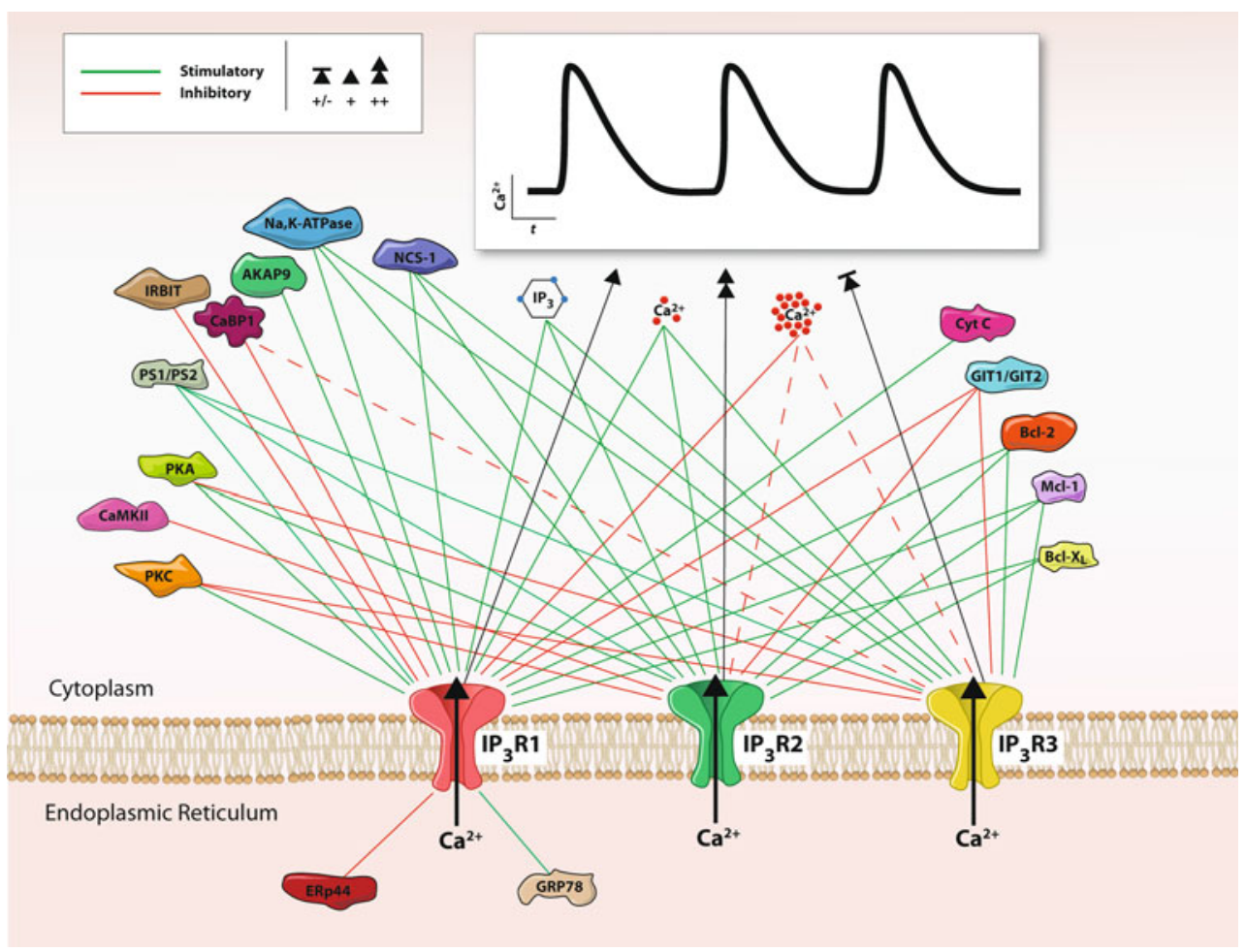


$\mathrm{CaBP} 1$, one of the neuronal $\mathrm{Ca}^{2+}$ binding proteins, was co-immunoprecipitated with $\mathrm{IP}_{3} \mathrm{R} 1$ and $\mathrm{IP}_{3} \mathrm{R} 3$ [82]. The CaBP1-binding site was mapped in the ligand coupling/ suppressor domain of $\mathrm{IP}_{3} \mathrm{R} 1$. This interaction functionally inhibits $\mathrm{IP}_{3}$-dependent $\mathrm{Ca}^{2+}$ oscillations in COS-7 cells expressing $\mathrm{CaBP} 1$, in permeabilized COS-7 cells exposed to recombinant $\mathrm{CaBP} 1$, and in Xenopus oocytes injected with recombinant $\mathrm{CaBP} 1$.

$\mathrm{Na}, \mathrm{K}-\mathrm{ATPase}$, a plasma membrane ion pump, directly binds to the $\mathrm{IP}_{3}$ binding-domain of all three $\mathrm{IP}_{3} \mathrm{R}$ subtypes through its $\mathrm{NH}_{2}$-terminal tail $[83,84]$. In the presence of ouabain, Na,K-ATPase triggers $\mathrm{IP}_{3}$-dependent $\mathrm{Ca}^{2+}$ oscillations in COS-7 cells and in primary culture of rat renal proximal tubule cells. Overexpression of a peptide corresponding to the wild type $\mathrm{NH}_{2}$-terminal tail of $\mathrm{Na}, \mathrm{K}$ ATPase decreased the number of cells exhibiting $\mathrm{Ca}^{2+}$ oscillations, an effect not observed when a mutant type that does not bind to $\mathrm{IP}_{3} \mathrm{R}$ was used.

IRBIT was identified to bind to the $\mathrm{IP}_{3}$ binding core of $\mathrm{IP}_{3} \mathrm{R} 1$ [85]. This interaction suppresses the activation of $\mathrm{IP}_{3} \mathrm{R}$ by regulating the $\mathrm{IP}_{3}$ sensitivity of $\mathrm{IP}_{3} \mathrm{R} 1$. Knockdown of IRBIT in HeLa cells increases ATP-induced cytosolic $\mathrm{Ca}^{2+}$ oscillations.

AKAP9, one of the neuronal PKA-anchoring adaptor proteins, binds to the leucine/isoleucine zipper (LIZ) motif in the internal coupling domain of $\mathrm{IP}_{3} \mathrm{R} 1$ [86]. Expression of a 36-residues LIZ fragment, which can disrupt the $\mathrm{IP}_{3} \mathrm{R} 1-\mathrm{AKAP} 9$ association, reduces the frequency of $\mathrm{Ca}^{2+}$ oscillations induced by application of dopamine in primary culture of medium spiny neuron [87].

Presenilins (PS), including PS1 and PS2, are proteins bound to the gamma-secretase protease complex. Mutations in the genes encoding PS1 and PS2 are the major cause of familial Alzheimer's disease (FAD). Wildtype and FADmutants of PS1 and PS2 have been co-immunoprecipitated with $\mathrm{IP}_{3} \mathrm{R} 1$ and $\mathrm{IP}_{3} \mathrm{R} 3$ [88, 89]. These interactions exert profound stimulatory effects on the $\mathrm{IP}_{3} \mathrm{R}$ gating activity. Mutated PSs were demonstrated to increase frequency of both spontaneous $\mathrm{Ca}^{2+}$ oscillations and $\mathrm{Ca}^{2+}$ oscillations triggered by cross-linking the $\mathrm{B}$ cell receptor with $\mathrm{IgM}$ antibody in both DT40 cells and FAD patient B cells.

ERp44 is an ER lumenal protein of the thioredoxin family. Depending on the oxidative status in the ER lumen, it can interact directly with the third $\mathrm{IP}_{3} \mathrm{R} 1$ lumenal loop and inhibit its activity [90]. Knockdown of ERp44 in HeLa cells increases ATP-triggered cytosolic $\mathrm{Ca}^{2+}$ oscillations.

GRP78, another ER lumenal protein, also interacts with the third lumenal loop of the $\mathrm{IP}_{3} \mathrm{R} 1$ [91]. In contrast to ERp44, GRP78 enhances $\mathrm{IP}_{3} \mathrm{R} 1$ channel activity. Knockdown of GRP78 in HeLa cells decreases ATP-triggered $\mathrm{Ca}^{2+}$ oscillations, which is restored by re-expression of the protein.

$\mathrm{Bcl}-2, \mathrm{Bcl}-\mathrm{X}_{\mathrm{L}}$, and $\mathrm{Mcl}-1$, three anti-apoptotic proteins that belong to $\mathrm{Bcl}-2$ family, have been reported to bind to the CTT and/or the internal coupling domain of all three $\mathrm{IP}_{3} \mathrm{R}$ subtypes [78, 92-95]. Bcl-2 enhances $\mathrm{IP}_{3}$-mediated $\mathrm{Ca}^{2+}$ oscillations induced by $\mathrm{T}$ cell receptor activation in WEHI7.2 cells, Jurkat cells, and wild type DT40 cells [78, 92, 94, 96], whereas $\mathrm{Ca}^{2+}$ oscillations induced by serum withdrawal in NIH-3T3 murine fibroblasts are dampened [97]. Expression of Bcl- $X_{L}$ in wild type DT40 cells or in DT40 cells engineered to express each $\mathrm{IP}_{3} \mathrm{R}$ subtype increases the number of the cells exhibiting $\mathrm{Ca}^{2+}$ oscillations as well as the oscillatory frequency [93, 95]. Interaction of Mcl-1 with $\mathrm{IP}_{3} \mathrm{R}$ increases the number of DT40 cells exhibiting anti-B cell receptor antibody induced $\mathrm{Ca}^{2+}$ oscillations [78]. Bcl-2 and Mcl-1 also increase the number of cells exhibiting $\mathrm{Ca}^{2+}$ oscillations and the amplitude and/ or the frequency of spontaneous $\mathrm{Ca}^{2+}$ oscillations in DT 40 cells [78].

Cytochrome C, one of the key components of the apoptotic cascade, was found to selectively and directly bind to $\mathrm{IP}_{3} \mathrm{R} 1 \mathrm{CTT}$ during early apoptosis via a cluster of glutamic acid residues (binding to $\mathrm{IP}_{3} \mathrm{R} 2$ and $\mathrm{IP}_{3} \mathrm{R} 3$ were not confirmed), resulting in staurosporine-induced sustained $\mathrm{Ca}^{2+}$ oscillations [98, 99].

G-protein-coupled receptor kinase-interacting proteins (GIT), including GIT1 and GIT2, bind to the CTT of all three $\mathrm{IP}_{3} \mathrm{R}$ subtypes, but have stronger binding affinity to $\mathrm{IP}_{3} \mathrm{R} 2$ (more than 10- and 20-fold as compared to $\mathrm{IP}_{3} \mathrm{R} 1$ and $\mathrm{IP}_{3} \mathrm{R} 3$, respectively), and inhibit IICR [81]. Knockdown of GIT proteins in HeLa or COS-7 cells increases the number of cells exhibiting $\mathrm{Ca}^{2+}$ oscillations.

Neuronal $\mathrm{Ca}^{2+}$ sensor 1 (NCS-1), a $\mathrm{Ca}^{2+}$ binding protein whose expression could be enhanced by application of Taxol, a natural product for the treatment of solid tumors, was co-immunoprecipitated with all three subtypes of $\mathrm{IP}_{3} \mathrm{R}$ $[80,100]$. The NCS-1-IP ${ }_{3} R$ interaction increases the number of cells exhibiting $\mathrm{IP}_{3} \mathrm{R}$-dependent $\mathrm{Ca}^{2+}$ oscillations in SH-SY5Y human neuroblastoma cells [100] and the frequency of spontaneous $\mathrm{Ca}^{2+}$ oscillations in rat ventricular cardiomyocytes [80].

The diversity in distribution of associated proteins and/ or $I_{3} R$ subtypes is essential for the versatility of $I_{3} R$ subtype-dependent $\mathrm{Ca}^{2+}$ oscillations in different cell types. More information, however, is required for determining the individual role of each separate subtype in modulating cytosolic $\mathrm{Ca}^{2+}$ oscillations.

\section{Conclusion and Future Directions}

It is evident that the different $\mathrm{IP}_{3} \mathrm{R}$ subtypes are regulated by a large number of cellular mechanisms that varies in a cell type-specific manner. In this review we have focused on $\mathrm{IP}_{3} \mathrm{R}$ subtype-specific modulation of $\mathrm{Ca}^{2+}$ oscillations. $\mathrm{Ca}^{2+}$ oscillations are repetitive increases in the cytosolic 
$\mathrm{Ca}^{2+}$ concentration that are used by the cell to convey information within or between cells. The oscillatory $\mathrm{Ca}^{2+}$ signal is known to be initiated at the onset of fertilization [101-103] and to continue throughout life to control a vast array of cellular processes as diverse as proliferation, differentiation, development, learning and memory, contraction, secretion, and cell death $[1,15]$. Altered intracellular $\mathrm{Ca}^{2+}$ signaling has been linked to many diseases, such as Hungtington's, Alzheimer's and Parkinson's diseases, amyotrophic lateral sclerosis, schizophrenia, spinocerebellar ataxias, heart failure, polycystic kidney disease, and human immunodeficiency virus infection [104-107]. It is therefore essential to determine the molecular mechanisms involved in the generation of intracellular $\mathrm{Ca}^{2+}$ oscillations. Additionally, $\mathrm{Ca}^{2+}$ oscillations are known to encode information in their frequency and amplitude to activate various specific downstream targets [15-17]. Efforts to understand the nature of these "cellular radio signals" started at the same time as $\mathrm{Ca}^{2+}$ oscillations were discovered and have resulted in a large number of publications $[16-18,22,28,30,32,35,37,39,42,47,56,60,83,100-$ $102]$, most of which is cell type- and agonist-specific. To determine the associations between (1) stimulus, (2) $\mathrm{Ca}^{2+}$ oscillation, and (3) activation of a specific downstream cellular process, future studies will have to consider the molecular partners involved in each step. The recent rapid development of sophisticated molecular and genetic tools, such as small interfering RNA [108] and optogenetics [109], will surely advance our future knowledge about $\mathrm{IP}_{3} \mathrm{R}$ subtype-specific regulation of $\mathrm{Ca}^{2+}$ oscillations.

Acknowledgements This work was supported by the Swedish Research Council (Dnr 2005-6682, 2009-3364, 2010-4392 and DBRM), the Foundation for Strategic Research (CEDB), the Knut and Alice Wallenberg Foundation (CLICK and Research Fellow to PU), The Royal Swedish Academy of Sciences (PU), and Fredrik and Ingrid Thuring's Foundation (PU). The authors wish to thank Dr. Arindam Majumdar for proof reading of the manuscript.

Open Access This article is distributed under the terms of the Creative Commons Attribution Noncommercial License which permits any noncommercial use, distribution, and reproduction in any medium, provided the original author(s) and source are credited.

\section{References}

1. Mikoshiba K (2007) IP3 receptor/ $\mathrm{Ca}^{2+}$ channel: from discovery to new signaling concepts. J Neurochem 102:1426-1446

2. Berridge MJ (1993) Inositol trisphosphate, calcium signalling. Nature 361:315-325

3. Foskett JK, White C, Cheung KH, Mak DO (2007) Inositol trisphosphate receptor $\mathrm{Ca}^{2+}$ release channels. Physiol Rev 87:593-658

4. Mikoshiba K, Changeux JP (1978) Morphological, biochemical studies on isolated molecular, granular layers from bovine cerebellum. Brain Res 142:487-504
5. Mikoshiba K, Huchet M, Changeux JP (1979) Biochemical, immunological studies on the $\mathrm{P} 400$ protein, a protein characteristic of the Purkinje cell from mouse, rat cerebellum. Dev Neurosci 2:254-275

6. Furuichi T, Yoshikawa S, Miyawaki A, Wada K, Maeda N, Mikoshiba K (1989) Primary structure, functional expression of the inositol 1, 4, 5-trisphosphate-binding protein P400. Nature 342:32-38

7. Wojcikiewicz RJ (1995) Type I, II, and III inositol 1, 4, 5-trisphosphate receptors are unequally susceptible to down-regulation, are expressed in markedly different proportions in different cell types. J Biol Chem 270:11678-11683

8. De Smedt H, Missiaen L, Parys JB, Bootman MD, Mertens L, Van Den Bosch L, Casteels R (1994) Determination of relative amounts of inositol trisphosphate receptor mRNA isoforms by ratio polymerase chain reaction. $J$ Biol Chem 269:21691-21698

9. Newton CL, Mignery GA, Sudhof TC (1994) Co-expression in vertebrate tissues, cell lines of multiple inositol 1, 4, 5-trisphosphate (InsP3) receptors with distinct affinities for InsP3. J Biol Chem 269:28613-28619

10. Uchida K, Miyauchi H, Furuichi T, Michikawa T, Mikoshiba K (2003) Critical regions for activation gating of the inositol 1, 4, 5-trisphosphate receptor. J Biol Chem 278:16551-16560

11. Iwai M, Tateishi Y, Hattori M, Mizutani A, Nakamura T, Futatsugi A, Inoue $\mathrm{T}$, Furuichi $\mathrm{T}$, Michikawa $\mathrm{T}$, Mikoshiba $\mathrm{K}$ (2005) Molecular cloning of mouse type 2, type 3 inositol 1, 4, 5-trisphosphate receptors, identification of a novel type 2 receptor splice variant. J Biol Chem 280:10305-10317

12. Taylor CW, Genazzani AA, Morris SA (1999) Expression of inositol trisphosphate receptors. Cell Calcium 26:237-251

13. Iwai M, Michikawa T, Bosanac I, Ikura M, Mikoshiba K (2007) Molecular basis of the isoform-specific ligand-binding affinity of inositol 1, 4, 5-trisphosphate receptors. J Biol Chem 282:12755-12764

14. Yoshikawa F, Morita M, Monkawa T, Michikawa T, Furuichi T, Mikoshiba K (1996) Mutational analysis of the ligand binding site of the inositol 1, 4, 5-trisphosphate receptor. J Biol Chem 271:18277-18284

15. Berridge MJ, Lipp P, Bootman MD (2000) The versatility, universality of calcium signalling. Nat Rev Mol Cell Biol $1: 11-21$

16. Fewtrell C (1993) $\mathrm{Ca}^{2+}$ oscillations in non-excitable cells. Annu Rev Physiol 55:427-454

17. Uhlen P, Fritz N (2010) Biochemistry of calcium oscillations. Biochem Biophys Res Commun 396:28-32

18. Uhlen P, Burch PM, Zito CI, Estrada M, Ehrlich BE, Bennett AM (2006) Gain-of-function/Noonan syndrome SHP-2/Ptpn11 mutants enhance calcium oscillations, impair NFAT signaling. Proc Natl Acad Sci U S A 103:2160-2165

19. Berridge MJ, Bootman MD, Roderick HL (2003) Calcium signalling: dynamics, homeostasis, remodelling. Nat Rev Mol Cell Biol 4:517-529

20. Finch EA, Turner TJ, Goldin SM (1991) Calcium as a coagonist of inositol 1, 4, 5-trisphosphate-induced calcium release. Science 252:443-446

21. Bezprozvanny I, Watras J, Ehrlich BE (1991) Bell-shaped calcium-response curves of $\operatorname{Ins}(1,4,5) \mathrm{P} 3$-and calcium-gated channels from endoplasmic reticulum of cerebellum. Nature 351:751-754

22. Hajnoczky G, Thomas AP (1997) Minimal requirements for calcium oscillations driven by the IP3 receptor. EMBO J 16:3533-3543

23. Zimmermann B (2000) Control of InsP3-induced $\mathrm{Ca}^{2+}$ oscillations in permeabilized blowfly salivary gland cells: contribution of mitochondria. J Physiol 525(Pt 3):707-719 
24. Dumollard R, Sardet C (2001) Three different calcium wave pacemakers in ascidian eggs. J Cell Sci 114:2471-2481

25. Miyakawa T, Mizushima A, Hirose K, Yamazawa T, Bezprozvanny I, Kurosaki T, Iino M (2001) $\mathrm{Ca}\left({ }^{2+}\right)$-sensor region of IP(3) receptor controls intracellular $\mathrm{Ca}^{2+}$ ) signaling. EMBO J 20:1674-1680

26. Tanaka Y, Tashjian AH Jr (1994) Thimerosal potentiates $\mathrm{Ca}^{2+}$ release mediated by both the inositol 1, 4, 5-trisphosphate, the ryanodine receptors in sea urchin eggs. Implications for mechanistic studies on $\mathrm{Ca}^{2+}$ signaling. J Biol Chem 269: 11247-11253

27. Falcke M, Tsimring L, Levine $H$ (2000) Stochastic spreading of intracellular $\mathrm{Ca}^{2+}$ ) release. Phys Rev E Stat Phys Plasmas Fluids Relat Interdiscip Topics 62:2636-2643

28. Schuster S, Marhl M, Hofer T (2002) Modelling of simple, complex calcium oscillations. From single-cell responses to intercellular signalling. Eur J Biochem 269:1333-1355

29. Hirose K, Kadowaki S, Tanabe M, Takeshima H, Iino M (1999) Spatiotemporal dynamics of inositol 1, 4, 5-trisphosphate that underlies complex $\mathrm{Ca}^{2+}$ mobilization patterns. Science 284:1527-1530

30. Nash MS, Young KW, Challiss RA, Nahorski SR (2001) Intracellular signalling. Receptor-specific messenger oscillations. Nature 413:381-382

31. Nash MS, Young KW, Willars GB, Challiss RA, Nahorski SR (2001) Single-cell imaging of graded Ins $(1,4,5) \mathrm{P} 3$ production following G-protein-coupled-receptor activation. Biochem J 356:137-142

32. Young KW, Nash MS, Challiss RA, Nahorski SR (2003) Role of $\mathrm{Ca}^{2+}$ feedback on single cell inositol 1, 4, 5-trisphosphate oscillations mediated by G-protein-coupled receptors. J Biol Chem 278:20753-20760

33. Matsu-ura T, Michikawa T, Inoue T, Miyawaki A, Yoshida M, Mikoshiba K (2006) Cytosolic inositol 1, 4, 5-trisphosphate dynamics during intracellular calcium oscillations in living cells. J Cell Biol 173:755-765

34. Bartlett PJ, Young KW, Nahorski SR, Challiss RA (2005) Single cell analysis and temporal profiling of agonist-mediated inositol 1, 4, 5-trisphosphate, $\mathrm{Ca}^{2+}$, diacylglycerol, and protein kinase C signaling using fluorescent biosensors. J Biol Chem 280:21837-21846

35. Tamarina NA, Kuznetsov A, Rhodes CJ, Bindokas VP, Philipson LH (2005) Inositol (1, 4, 5)-trisphosphate dynamics and intracellular calcium oscillations in pancreatic beta-cells. Diabetes $54: 3073-3081$

36. Miyakawa T, Maeda A, Yamazawa T, Hirose K, Kurosaki T, Iino $\mathrm{M}$ (1999) Encoding of $\mathrm{Ca}^{2+}$ signals by differential expression of IP3 receptor subtypes. EMBO J 18:1303-1308

37. Morel JL, Fritz N, Lavie JL, Mironneau J (2003) Crucial role of type 2 inositol 1, 4, 5-trisphosphate receptors for acetylcholineinduced $\mathrm{Ca}^{2+}$ oscillations in vascular myocytes. Arterioscler Thromb Vasc Biol 23:1567-1575

38. Hattori M, Suzuki AZ, Higo T, Miyauchi H, Michikawa T, Nakamura T, Inoue T, Mikoshiba K (2004) Distinct roles of inositol 1, 4, 5-trisphosphate receptor types 1 and 3 in $\mathrm{Ca}^{2+}$ signaling. J Biol Chem 279:11967-11975

39. Almirza WH, Peters PH, van Meerwijk WP, van Zoelen EJ, Theuvenet AP (2010) Different roles of inositol 1, 4, 5-trisphosphate receptor subtypes in prostaglandin $\mathrm{F}$ (2alpha)-induced calcium oscillations and pacemaking activity of NRK fibroblasts. Cell Calcium 47:544-553

40. Tovey SC, de Smet P, Lipp P, Thomas D, Young KW, Missiaen L, De Smedt H, Parys JB, Berridge MJ, Thuring J, Holmes A, Bootman MD (2001) Calcium puffs are generic InsP(3)-activated elementary calcium signals and are downregulated by prolonged hormonal stimulation to inhibit cellular calcium responses. J Cell Sci 114:3979-3989

41. Regimbald-Dumas Y, Fregeau MO, Guillemette G (2011) Mammalian target of rapamycin (mTOR) phosphorylates inositol 1, 4, 5-trisphosphate receptor type 2 and increases its $\left.\mathrm{Ca}^{2+}\right)$ release activity. Cell Signal 23:71-79

42. Kuroda Y, Hisatsune C, Nakamura T, Matsuo K, Mikoshiba K (2008) Osteoblasts induce $\mathrm{Ca}^{2+}$ oscillation-independent NFATc1 activation during osteoclastogenesis. Proc Natl Acad Sci USA 105:8643-8648

43. Caron AZ, Chaloux B, Arguin G, Guillemette G (2007) Protein kinase $\mathrm{C}$ decreases the apparent affinity of the inositol 1, 4, 5-trisphosphate receptor type 3 in RINm5F cells. Cell Calcium 42:323-331

44. Hernandez E, Leite MF, Guerra MT, Kruglov EA, Bruna-Romero O, Rodrigues MA, Gomes DA, Giordano FJ, Dranoff JA, Nathanson MH (2007) The spatial distribution of inositol 1, 4, 5-trisphosphate receptor isoforms shapes $\mathrm{Ca}^{2+}$ waves. J Biol Chem 282:10057-10067

45. Kim JC, Son MJ, Subedi KP, Kim do H, Woo SH (2010) IP3induced cytosolic and nuclear $\mathrm{Ca}^{2+}$ signals in $\mathrm{HL}-1$ atrial myocytes: possible role of IP3 receptor subtypes. Mol Cells 29:387-395

46. Shuai JW, Jung P (2003) Optimal ion channel clustering for intracellular calcium signaling. Proc Natl Acad Sci U S A 100:506-510

47. Li M, Zacharia J, Sun X, Wier WG (2008) Effects of siRNA knock-down of TRPC6 and $\operatorname{InsP}(3) \mathrm{R} 1$ in vasopressin-induced $\mathrm{Ca}^{2+}$ ) oscillations of $\mathrm{A} 7 \mathrm{r} 5$ vascular smooth muscle cells. Pharmacol Res 58:308-315

48. Futatsugi A, Nakamura T, Yamada MK, Ebisui E, Nakamura K, Uchida K, Kitaguchi T, Takahashi-Iwanaga H, Noda T, Aruga J, Mikoshiba K (2005) IP3 receptor types 2 and 3 mediate exocrine secretion underlying energy metabolism. Science 309: 2232-2234

49. Joseph SK, Bokkala S, Boehning D, Zeigler S (2000) Factors determining the composition of inositol trisphosphate receptor hetero-oligomers expressed in COS cells. J Biol Chem 275:16084-16090

50. Maeda N, Kawasaki T, Nakade S, Yokota N, Taguchi T, Kasai M, Mikoshiba K (1991) Structural and functional characterization of inositol 1, 4, 5-trisphosphate receptor channel from mouse cerebellum. J Biol Chem 266:1109-1116

51. Monkawa T, Miyawaki A, Sugiyama T, Yoneshima $H$, Yamamoto-Hino M, Furuichi T, Saruta T, Hasegawa M, Mikoshiba K (1995) Heterotetrameric complex formation of inositol 1, 4, 5-trisphosphate receptor subunits. J Biol Chem 270:14700-14704

52. Sudhof TC, Newton CL, Archer BT 3rd, Ushkaryov YA, Mignery GA (1991) Structure of a novel InsP3 receptor. EMBO J 10:3199-3206

53. Wojcikiewicz RJ, Luo SG (1998) Differences among type I, II, and III inositol-1, 4, 5-trisphosphate receptors in ligand-binding affinity influence the sensitivity of calcium stores to inositol-1, 4, 5-trisphosphate. Mol Pharmacol 53:656-662

54. Nerou EP, Riley AM, Potter BV, Taylor CW (2001) Selective recognition of inositol phosphates by subtypes of the inositol trisphosphate receptor. Biochem J 355:59-69

55. Tu H, Wang Z, Nosyreva E, De Smedt H, Bezprozvanny I (2005) Functional characterization of mammalian inositol 1, 4, 5-trisphosphate receptor isoforms. Biophys J 88:1046-1055

56. Berridge MJ (1990) Calcium oscillations. J Biol Chem 265:9583-9586

57. Sienaert I, De Smedt H, Parys JB, Missiaen L, Vanlingen S, Sipma H, Casteels R (1996) Characterization of a cytosolic and 
a luminal $\mathrm{Ca}^{2+}$ binding site in the type I inositol 1, 4, 5-trisphosphate receptor. J Biol Chem 271:27005-27012

58. Dupont G, Combettes L (2006) Modelling the effect of specific inositol 1, 4, 5-trisphosphate receptor isoforms on cellular $\mathrm{Ca}^{2+}$ signals. Biol Cell 98:171-182

59. Swatton JE, Morris SA, Cardy TJ, Taylor CW (1999) Type 3 inositol trisphosphate receptors in RINm5F cells are biphasically regulated by cytosolic $\mathrm{Ca}^{2+}$ and mediate quantal $\mathrm{Ca}^{2+}$ mobilization. Biochem J 344(Pt 1):55-60

60. Fritz N, Mironneau J, Macrez N, Morel JL (2008) Acetylcholine-induced $\mathrm{Ca}^{2+}$ oscillations are modulated by a $\mathrm{Ca}^{2+}$ regulation of InsP3R2 in rat portal vein myocytes. Pflugers Arch 456:277-283

61. Krizanova O, Ondrias K (2003) The inositol 1, 4, 5-trisphosphate receptor-transcriptional regulation and modulation by phosphorylation. Gen Physiol Biophys 22:295-311

62. Vanderheyden V, Devogelaere B, Missiaen L, De Smedt H, Bultynck G, Parys JB (2009) Regulation of inositol 1, 4, 5-trisphosphate-induced $\mathrm{Ca}^{2+}$ release by reversible phosphorylation and dephosphorylation. Biochim Biophys Acta 1793:959-970

63. Wagner LE 2nd, Li WH, Joseph SK, Yule DI (2004) Functional consequences of phosphomimetic mutations at key cAMPdependent protein kinase phosphorylation sites in the type 1 inositol 1, 4, 5-trisphosphate receptor. J Biol Chem 279:46242-46252

64. Ferris CD, Cameron AM, Bredt DS, Huganir RL, Snyder SH (1991) Inositol 1, 4, 5-trisphosphate receptor is phosphorylated by cyclic AMP-dependent protein kinase at serines 1755 and 1589. Biochem Biophys Res Commun 175:192-198

65. Wojcikiewicz RJ, Luo SG (1998) Phosphorylation of inositol 1, 4, 5-trisphosphate receptors by cAMP-dependent protein kinase. Type I, II, III receptors are differentially susceptible to phosphorylation, are phosphorylated in intact cells. J Biol Chem 273:5670-5677

66. Bruce JI, Shuttleworth TJ, Giovannucci DR, Yule DI (2002) Phosphorylation of inositol 1, 4, 5-trisphosphate receptors in parotid acinar cells. A mechanism for the synergistic effects of cAMP on $\mathrm{Ca}^{2+}$ signaling. J Biol Chem 277:1340-1348

67. Regimbald-Dumas Y, Arguin G, Fregeau MO, Guillemette G (2007) cAMP-dependent protein kinase enhances inositol 1, 4, 5-trisphosphate-induced $\mathrm{Ca}^{2+}$ release in AR4-2 $\mathrm{J}$ cells. J Cell Biochem 101:609-618

68. Aromolaran AA, Blatter LA (2005) Modulation of intracellular $\mathrm{Ca}^{2+}$ release and capacitative $\mathrm{Ca}^{2+}$ entry by CaMKII inhibitors in bovine vascular endothelial cells. Am J Physiol Cell Physiol 289:C1426-1436

69. Ibarra C, Estrada M, Carrasco L, Chiong M, Liberona JL, Cardenas C, Diaz-Araya G, Jaimovich E, Lavandero S (2004) Insulin-like growth factor-1 induces an inositol 1, 4, 5-trisphosphate-dependent increase in nuclear and cytosolic calcium in cultured rat cardiac myocytes. J Biol Chem 279:7554-7565

70. Bare DJ, Kettlun CS, Liang M, Bers DM, Mignery GA (2005) Cardiac type 2 inositol 1, 4, 5-trisphosphate receptor: interaction and modulation by calcium/calmodulin-dependent protein kinase II. J Biol Chem 280:15912-15920

71. Zima AV, Bare DJ, Mignery GA, Blatter LA (2007) IP3dependent nuclear $\mathrm{Ca}^{2+}$ signalling in the mammalian heart. J Physiol 584:601-611

72. Zhu DM, Tekle E, Chock PB, Huang CY (1996) Reversible phosphorylation as a controlling factor for sustaining calcium oscillations in HeLa cells: Involvement of calmodulin-dependent kinase II and a calyculin A-inhibitable phosphatase. Biochemistry 35:7214-7223

73. Matter N, Ritz MF, Freyermuth S, Rogue P, Malviya AN (1993) Stimulation of nuclear protein kinase $\mathrm{C}$ leads to phosphorylation of nuclear inositol 1, 4, 5-trisphosphate receptor and accelerated calcium release by inositol 1, 4, 5-trisphosphate from isolated rat liver nuclei. J Biol Chem 268:732-736

74. Vermassen E, Fissore RA, Nadif Kasri N, Vanderheyden V, Callewaert G, Missiaen L, Parys JB, De Smedt H (2004) Regulation of the phosphorylation of the inositol 1, 4, 5-trisphosphate receptor by protein kinase C. Biochem Biophys Res Commun 319:888-893

75. Arguin G, Regimbald-Dumas Y, Fregeau MO, Caron AZ, Guillemette G (2007) Protein kinase C phosphorylates the inositol 1, 4, 5-trisphosphate receptor type 2 and decreases the mobilization of $\mathrm{Ca}^{2+}$ in pancreatoma AR4-2J cells. J Endocrinol 192:659-668

76. Patel S, Joseph SK, Thomas AP (1999) Molecular properties of inositol 1, 4, 5-trisphosphate receptors. Cell Calcium $25: 247-264$

77. Choe CU, Ehrlich BE (2006) The inositol 1,4,5-trisphosphate receptor (IP3R) and its regulators: sometimes good and sometimes bad teamwork. Sci STKE re15

78. Eckenrode EF, Yang J, Velmurugan GV, Foskett JK, White C (2010) Apoptosis protection by Mcl-1 and Bcl-2 modulation of inositol 1, 4, 5-trisphosphate receptor-dependent $\mathrm{Ca}^{2+}$ signaling. J Biol Chem 285:13678-13684

79. Kawaai K, Hisatsune C, Kuroda Y, Mizutani A, Tashiro T, Mikoshiba K (2009) $80 \mathrm{~K}-\mathrm{H}$ interacts with inositol 1, 4, 5-trisphosphate (IP3) receptors and regulates IP3-induced calcium release activity. J Biol Chem 284:372-380

80. Zhang K, Heidrich FM, DeGray B, Boehmerle W, Ehrlich BE (2010) Paclitaxel accelerates spontaneous calcium oscillations in cardiomyocytes by interacting with NCS-1 and the InsP3R. J Mol Cell Cardiol 49:829-835

81. Zhang S, Hisatsune C, Matsu-Ura T, Mikoshiba K (2009) G-protein-coupled receptor kinase-interacting proteins inhibit apoptosis by inositol 1, 4, 5-triphosphate receptor-mediated $\mathrm{Ca}^{2+}$ signal regulation. J Biol Chem 284:29158-29169

82. Kasri NN, Holmes AM, Bultynck G, Parys JB, Bootman MD, Rietdorf K, Missiaen L, McDonald F, De Smedt H, Conway SJ, Holmes AB, Berridge MJ, Roderick HL (2004) Regulation of InsP3 receptor activity by neuronal $\mathrm{Ca}^{2+}$-binding proteins. EMBO J 23:312-321

83. Miyakawa-Naito A, Uhlen P, Lal M, Aizman O, Mikoshiba K, Brismar H, Zelenin S, Aperia A (2003) Cell signaling microdomain with $\mathrm{Na}$, K-ATPase and inositol 1, 4, 5-trisphosphate receptor generates calcium oscillations. J Biol Chem 278: 50355-50361

84. Zhang S, Malmersjo S, Li J, Ando H, Aizman O, Uhlen P, Mikoshiba K, Aperia A (2006) Distinct role of the N-terminal tail of the Na, K-ATPase catalytic subunit as a signal transducer. J Biol Chem 281:21954-21962

85. Ando H, Mizutani A, Kiefer H, Tsuzurugi D, Michikawa T, Mikoshiba K (2006) IRBIT suppresses IP3 receptor activity by competing with IP3 for the common binding site on the IP3 receptor. Mol Cell 22:795-806

86. Tu H, Tang TS, Wang Z, Bezprozvanny I (2004) Association of type 1 inositol 1, 4, 5-trisphosphate receptor with AKAP9 (Yotiao) and protein kinase A. J Biol Chem 279:19375-19382

87. Tang TS, Bezprozvanny I (2004) Dopamine receptor-mediated $\left.\mathrm{Ca}^{2+}\right)$ signaling in striatal medium spiny neurons. J Biol Chem 279:42082-42094

88. Cheung KH, Shineman D, Muller M, Cardenas C, Mei L, Yang J, Tomita T, Iwatsubo T, Lee VM, Foskett JK (2008) Mechanism of $\mathrm{Ca}^{2+}$ disruption in Alzheimer's disease by presenilin regulation of InsP3 receptor channel gating. Neuron 58:871-883

89. Muller M, Cheung KH, Foskett JK (2010) Enhanced ROS Generation Mediated by Alzheimer's Disease Presenilin Regulation of $\operatorname{InsP}(3) \mathrm{R} \mathrm{Ca}\left({ }^{2+}\right)$ Signaling. Antioxid Redox Signal 
90. Higo T, Hattori M, Nakamura T, Natsume T, Michikawa T, Mikoshiba K (2005) Subtype-specific and ER lumenal environment-dependent regulation of inositol 1, 4, 5-trisphosphate receptor type 1 by ERp44. Cell 120:85-98

91. Higo T, Hamada K, Hisatsune C, Nukina N, Hashikawa T, Hattori M, Nakamura T, Mikoshiba K (2010) Mechanism of ER stress-induced brain damage by $\operatorname{IP}(3)$ receptor. Neuron 68:865-878

92. Chen R, Valencia I, Zhong F, McColl KS, Roderick HL, Bootman MD, Berridge MJ, Conway SJ, Holmes AB, Mignery GA, Velez P, Distelhorst CW (2004) Bcl-2 functionally interacts with inositol 1, 4, 5-trisphosphate receptors to regulate calcium release from the ER in response to inositol 1, 4, 5-trisphosphate. J Cell Biol 166:193-203

93. Li C, Wang X, Vais H, Thompson CB, Foskett JK, White C (2007) Apoptosis regulation by $\mathrm{Bcl}-\mathrm{x}(\mathrm{L})$ modulation of mammalian inositol 1, 4, 5-trisphosphate receptor channel isoform gating. Proc Natl Acad Sci U S A 104:12565-12570

94. Rong YP, Aromolaran AS, Bultynck G, Zhong F, Li X, McColl K, Matsuyama S, Herlitze S, Roderick HL, Bootman MD, Mignery GA, Parys JB, De Smedt H, Distelhorst CW (2008) Targeting Bcl-2-IP3 receptor interaction to reverse Bcl-2's inhibition of apoptotic calcium signals. Mol Cell 31:255-265

95. White C, Li C, Yang J, Petrenko NB, Madesh M, Thompson CB, Foskett JK (2005) The endoplasmic reticulum gateway to apoptosis by Bcl-X(L) modulation of the InsP3R. Nat Cell Biol 7:1021-1028

96. Zhong F, Davis MC, McColl KS, Distelhorst CW (2006) Bcl-2 differentially regulates $\mathrm{Ca}^{2+}$ signals according to the strength of $\mathrm{T}$ cell receptor activation. J Cell Biol 172:127-137

97. Magnelli L, Cinelli M, Turchetti A, Chiarugi VP (1994) Bcl-2 overexpression abolishes early calcium waving preceding apoptosis in NIH-3T3 murine fibroblasts. Biochem Biophys Res Commun 204:84-90

98. Boehning D, Patterson RL, Sedaghat L, Glebova NO, Kurosaki T, Snyder SH (2003) Cytochrome c binds to inositol $(1,4,5)$ trisphosphate receptors, amplifying calcium-dependent apoptosis. Nat Cell Biol 5:1051-1061
99. Boehning D, van Rossum DB, Patterson RL, Snyder SH (2005) A peptide inhibitor of cytochrome c/inositol 1, 4, 5-trisphosphate receptor binding blocks intrinsic and extrinsic cell death pathways. Proc Natl Acad Sci U S A 102:1466-1471

100. Boehmerle W, Splittgerber U, Lazarus MB, McKenzie KM, Johnston DG, Austin DJ, Ehrlich BE (2006) Paclitaxel induces calcium oscillations via an inositol 1, 4, 5-trisphosphate receptor and neuronal calcium sensor 1-dependent mechanism. Proc Natl Acad Sci U S A 103:18356-18361

101. Cuthbertson KS, Cobbold PH (1985) Phorbol ester and sperm activate mouse oocytes by inducing sustained oscillations in cell $\mathrm{Ca} 2+$. Nature 316:541-542

102. Halet G, Marangos P, Fitzharris G, Carroll J (2003) $\mathrm{Ca}^{2+}$ oscillations at fertilization in mammals. Biochem Soc Trans 31:907-911

103. Shiraishi K, Okada A, Shirakawa H, Nakanishi S, Mikoshiba K, Miyazaki S (1995) Developmental changes in the distribution of the endoplasmic reticulum and inositol 1, 4, 5-trisphosphate receptors and the spatial pattern of $\mathrm{Ca}^{2+}$ release during maturation of hamster oocytes. Dev Biol 170:594-606

104. Bezprozvanny I (2009) Calcium signaling and neurodegenerative diseases. Trends Mol Med 15:89-100

105. Ehrlich LS, Medina GN, Khan MB, Powell MD, Mikoshiba K, Carter CA (2010) Activation of the inositol (1, 4, 5)-triphosphate calcium gate receptor is required for HIV-1 Gag release. J Virol 84:6438-6451

106. Foskett JK (2010) Inositol trisphosphate receptor $\mathrm{Ca}^{2+}$ release channels in neurological diseases. Pflugers Arch 460:481-494

107. Wu G, Markowitz GS, Li L, D’Agati VD, Factor SM, Geng L, Tibara S, Tuchman J, Cai Y, Park JH, van Adelsberg J, Hou H Jr, Kucherlapati R, Edelmann W, Somlo S (2000) Cardiac defects and renal failure in mice with targeted mutations in Pkd2. Nat Genet 24:75-78

108. Elbashir SM, Harborth J, Lendeckel W, Yalcin A, Weber K, Tuschl T (2001) Duplexes of 21-nucleotide RNAs mediate RNA interference in cultured mammalian cells. Nature 411:494-498

109. Sohal VS, Zhang F, Yizhar O, Deisseroth K (2009) Parvalbumin neurons and gamma rhythms enhance cortical circuit performance. Nature 459:698-702 